\title{
Polysomaty in Cymbidium
}

\author{
Seiichi Fukai ${ }^{1}$, Atsushi Hasegawa ${ }^{2}$, and Masanori Goi ${ }^{3}$ \\ Faculty of Agriculture, Kagawa University, Miki-cho, 761-0795 Kagawa, \\ Japan
}

Additional index words. flow cytometry, orchid, Cymbidium, polysomaty

\begin{abstract}
Nuclear DNA content in various parts of Cymbidium plants was measured by flow cytometry. Two types of Cymbidium, protocorm-like body (PLB)-propagated epiphytic hybrids and rhizome-propagated terrestrial $C$. kanran Makino demonstrated polysomaty. Small shoots on PLBs of Cymbidium hybrids showed two peaks (2C and 4C) while PLBs showed four peaks, estimated to be $2 \mathrm{C}, 4 \mathrm{C}, 8 \mathrm{C}$, and $16 \mathrm{C}$. Roots and floral organs excluding ovaries of hybrids were highly polysomatic as were the rhizomes and roots of $C$. kanran. The patterns of polysomaty development were organ and developmental stage specific. Young leaves taken from in vitro plants are suitable material for determining the ploidy levels of Cymbidium plants by flow cytometry.
\end{abstract}

Cymbidium is among the most successful orchids as pot plants and cut flowers. Large numbers of new genotypes are released each year to meet consumer's demands. Recent genotypes of epiphytic Cymbidium hybrids are mostly triploid or tetraploid. The basic chromosome number of Cymbidium plants is $2 n=40$ with some exceptions (Aoyama, 1989). Speedy and reliable methods for ploidy determination are required for an effective breeding program. Precise information on ploidy levels is also beneficial to propagators and growers. Clonal multiplication of Cymbidium in vitro is achieved through protocormlike body (PLB) proliferation in epiphytic Cymbidium and through rhizome proliferation in terrestrial Cymbidium (Arditti, 1977; Hasegawa, 1987). Propagators must pay attention to the genetic instability of propagules including altered ploidy levels. Growers will benefit from information on ploidy levels of new genotypes, which affect growth characteristics.

Flow cytometry is a powerful tool to determine the ploidy level of large numbers of samples within a short time (Dolezel, 1997). Recently, polysomaty has been reported in the orchids Phalaenopsis and Dendrobium by using flow cytometry (Jones and Kuehnle, 1998; Mii et al., 1997). Nagl (1972) reported DNA amplification in PLB parenchyma cells in Cymbidium. To determine the ploidy level of a plant by flow cytometry, the understanding of polysomaty development in each organ is required. The aim of this work is to characterize polysomaty in various organs of Cymbidium and assess which are most suitable for ploidy determination by flow cytometry.

Received for publication 21 Aug. 2001. Accepted for publication 12 Feb. 2002. We thank BOI-U Co. for providing plant materials and Masahiro Mii for his valuable comments. We are grateful to Jaime Da Silva for his assistance in preparing the manuscript.

${ }^{1}$ Professor, to whom reprints request should be addressed; E-mail fukai@ag.kagawa-u.ac.jp

${ }^{2}$ Professor.

${ }^{3}$ Professor.

\section{Materials and Methods}

Two Cymbidium hybrids [Flower Dance 'Christmas Kiss'(4x) and Twilight Moon 'Day Light' $(2 x)$ ], were obtained from a commercial source (Boi-U Co., Kagawa, Japan) as both flowering plants and in vitro cultures. PLBs were cultured on medium containing half strength MS salts, $100 \mathrm{~g} \cdot \mathrm{L}^{-1}$ green banana fruit and $20 \mathrm{~g} \cdot \mathrm{L}^{-1}$ sucrose. PLBs with small shoots, leaves, pseudo bulbs and roots of in vitro young plants and leaves, flower stalks, pedicels, ovaries (premature, green), pollinia and petals of flowering plants grown in a greenhouse were collected from both genotypes. Rhizomes, roots and plantlets of $C$. kanran Makino were collected from rhizome cultures maintained on medium containing $3 \mathrm{~g} \cdot \mathrm{L}^{-1}$ Hyponex (complete soluble fertilizer, 6.5 N-6 P-19 K, Hyponex Co., Tokyo), $3 \mathrm{~g} \cdot \mathrm{L}^{-1}$ Bacto peptone, $1 \mathrm{mg} \cdot \mathrm{L}^{-1}$ 1-naphthaleneacetic acid (NAA), $30 \mathrm{~g} \cdot \mathrm{L}^{-1}$ sucrose and $2 \mathrm{~g} \cdot \mathrm{L}^{-1}$ gellan gum (Hasegawa, 1987) at Kagawa Univ. Farm, Japan.

To isolate nuclei, $25 \mathrm{~mm}^{2}$ of leaf and petal tissues, cross sections (1-2 mm thickness) of flower stalk, pedicel and green ovary, $1 \mathrm{~mm}$ root tips and $5 \mathrm{~mm}$ root tissues were prepared. Samples were collected from at least three independent plants and PLBs. Each sample tissue was chopped with a razor blade in a plastic dish with $0.5 \mathrm{~mL}$ of ice-cool buffer (solution A of high resolution DNA kit, Partech, Münster, Germany) and incubated on ice for 4 min. After filtration through a $20 \mu \mathrm{m}$ nylon mesh, $2.5 \mathrm{~mL}$ of the staining solution containing $10 \mathrm{~mm}$ Tris, $50 \mathrm{~mm}$ sodium citrate, $2 \mathrm{~mm} \mathrm{MgCl}_{2}, 1 \%$ (w/v) PVP K-30 (Wako Chemicals, Tokyo), $0.1 \%$ (v/v) Triton X-100 and $2 \mathrm{mg} \cdot \mathrm{L}^{-1} 4^{\prime}, 6$-diamidino-2-phenylindole (DAPI), pH 7.5 (Mishiba et al., 2000) was added to the nuclei sample. After 1 min of incubation on ice, the fluorescence of the nuclei was measured using Ploidy Analyzer PA (Partech, Münster, Germany) equipped with a mercury lamp and filter combinations of KG1, BG38, UG1, TK420, and GG435.

At least 8000 nuclei of three different samples were measured for each position of the plants. Data were represented as histo- grams showing relative nuclear DNA content of samples. The area of histogram peaks represented the number of nuclei for each ploidy level. Proportions of nuclei with different $\mathrm{C}$-values were calculated and subjected to analysis of variance. The $\mathrm{C}$-value of Cymbidium was determined by the measurement of the relative nuclear DNA content of pollen. Hordeum vulgare 'Bonus' ( $2 \mathrm{C}=9.41 \mathrm{pg}$, Kankanpaa et al, 1996) or Triticum aestivum 'Chikugo-izumi' leaf tissue were used as an internal standard to obtain reproducible results.

\section{Results}

Flow cytometoric analysis of pollinia resulted in two peaks (Fig. 1). One was a vegetative nucleus and another was a generative nucleus in which DNA had replicated and arrested in the G2 stage, typical of bicellulate pollen (Bino et al. 1990), these two peaks representing $1 \mathrm{C}$ and $2 \mathrm{C}$ values of the Cymbidium 'Day Light' genome.

Small shoots ( $5 \mathrm{~mm}$ in height) produced on PLBs of 'Day Light' (diploid) showed two peaks, one large and one small, representing G0/G1 (2C) and G2 (4C) stage cells, respectively. On the other hand, PLBs showed four peaks estimated to be $2 \mathrm{C}, 4 \mathrm{C}, 8 \mathrm{C}$ and $16 \mathrm{C}$ from the relative nuclear DNA contents (Fig. 1 ). The proportion of $2 \mathrm{C}$ cells was only $20 \%$ while 4C and 8C cells were $40 \%$ and $32 \%$, respectively. No difference was observed in the ploidy distribution when PLBs were divided into upper and lower parts. Samples of PLB epidermis that were excised carefully under a binocular microscope displayed only two peaks (2C and 4C), while the inner tissue showed four peaks $(2 \mathrm{C}-16 \mathrm{C})$ indicating high levels of polysomaty (data not shown).

Proportions of cells with each ploidy in different organs are summarized in Fig. 2. Leaves of in vitro plantlets ( $\approx 5 \mathrm{~cm}$ in height) and small shoots on PLBs had $\approx 90 \%$ and $80 \%$ of $2 \mathrm{C}$ cells, respectively, while the rest were $4 \mathrm{C}$. The basal part of the plantlet, which develops into a pseudobulb, had $2 \mathrm{C}$ to $8 \mathrm{C}$ cells. Root tips (1 mm in length) of in vitro plantlets had $2 \mathrm{C}$ to $16 \mathrm{C}$ cells. Roots taken from 1 to $3 \mathrm{~cm}$ above the root tip had no $2 \mathrm{C}$ cells. Proportions of higher ploidy cells $(8 \mathrm{C}$ and $16 \mathrm{C})$ were significantly increased $(P=$ $0.01)$ as the distance from the root tip increased.

'Christmas Kiss' (4x) showed the same developmental pattern of polysomaty as 'Day Light' if $4 \mathrm{C}-32 \mathrm{C}$ in the tetraploid is considered to correspond to $2 \mathrm{C}-16 \mathrm{C}$ in the diploid. 'Christmas Kiss' had a higher percentage of cells with lower ploidy levels than 'Day Light' (Fig. 2).

Flower stalks, pedicels and petals of 'Day Light' showed polysomaty having $2 \mathrm{C}$ to $16 \mathrm{C}$ cells (Fig. 3). On the other hand, ovaries had a significantly larger $(P=0.01)$ proportion of 2C cells. 'Christmas Kiss' showed a similar pattern of polysomaty development.

Rhizomes of $C$. kanran also showed polysomaty while shoots regenerated from rhizomes had no polysomaty (Fig. 4). Older parts of the rhizome consisted of cells with 
significantly higher $(P=0.01)$ ploidy levels in comparison with younger parts. Roots of $C$. kanran had polysomaty as observed in other Cymbidum hybrids (data not shown).

\section{Discussion}

Endoreduplication is cyclic DNA synthesis without cell division, leading to the existence of cells with different ploidy levels in a tissue or organ, which is termed polysomaty. Despite the appearance of polysomaty in a wide range of plant species (Cavallini et al., 1988; De Rocher et al., 1990; Galbraith et al., 1991; Gilissen et al., 1993; Mishiba and Mii 2000; Pijnacker et al., 1989; Smulders et al.,
1995), the function of polysomaty is not well understood. It has been claimed that polysomaty is related to nuclear genome size (De Rocher et al., 1990), interaction between nuclear and organelle genomes (Galbraith et al., 1991), cellular dimension (Melaragno et al., 1993), and auxin-induced cell elongation (Gilissen et al., 1993).

In this study both diploid and tetraploid genotypes showed a similar developmental pattern of polysomaty. The results showed that the patterns of polysomaty development were organ and developmental stage specific, agreeing with previous reports in various species (Galbraith et al., 1991; Gilissen et al., 1993; Smulders et al., 1994). The proportion of lower ploidy cells in the tetraploid genotype 'Christmas Kiss' was much higher than that in the diploid genotype 'Day Light' as also reported in tomato (Smulders et al., 1994) and Portulaca (Mishiba and Mii, 2000).

Genome size of diploid Cymbidium 'Day Light' estimated from the genome size of $H$. vulgare 'Bonus' $(2 \mathrm{C}=9.41 \mathrm{pg}$, Kankanpää et al., 1996) was $16.5 \mathrm{pg} / 2 \mathrm{C}$. The estimated DNA value from DAPI-stained samples depends on the base composition of the plant because DAPI binds preferentially to AT-rich regions of DNA (Dolezel et al. 1998). The limitation of DAPI-stained samples in this experiment must be taken into account to compare the value of genome size estimated by PI stain.
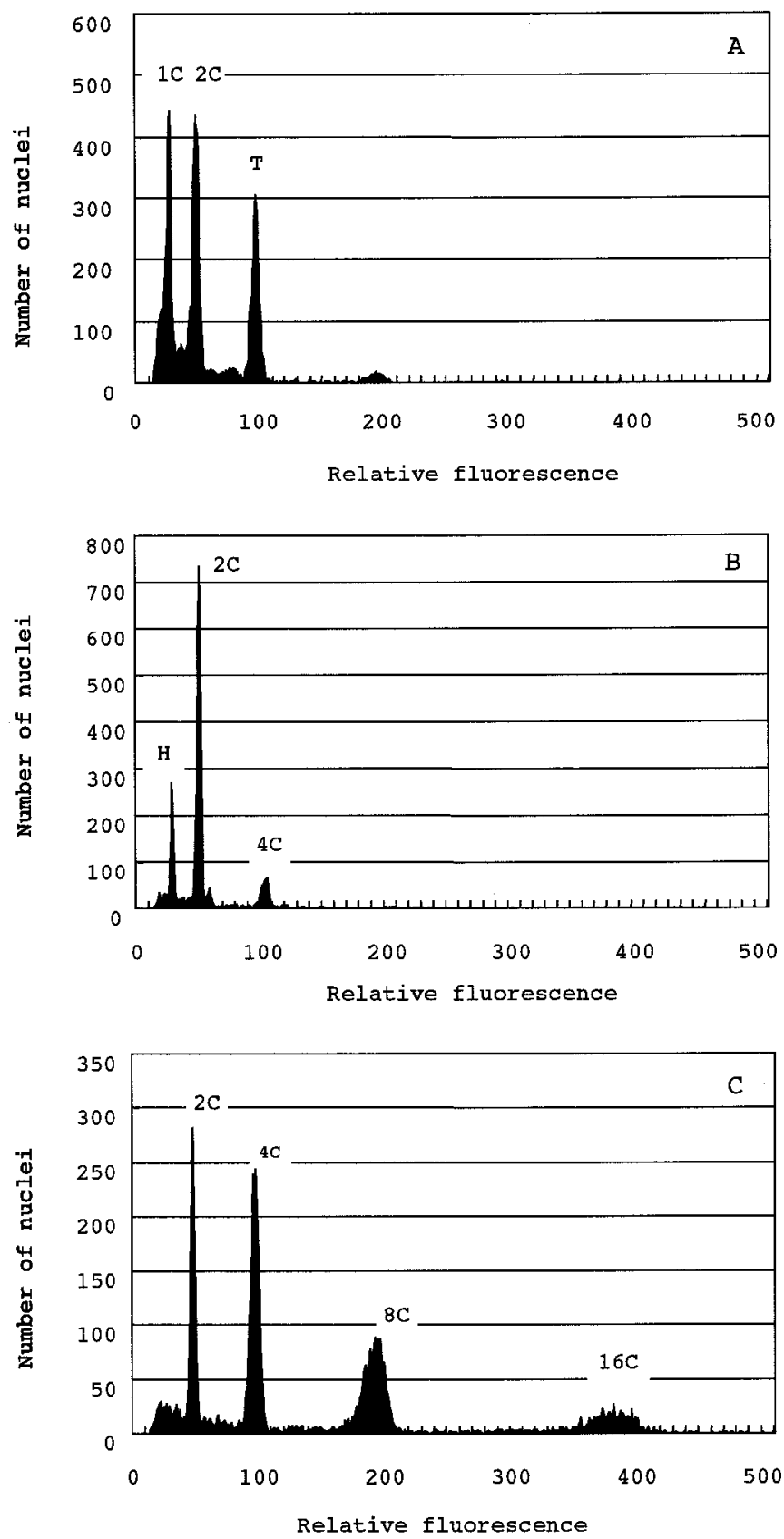

Fig. 1. Histograms of fluorescence intensity of nuclei. A) pollinia, T; wheat leaf as an internal standard, B) shoots on PLBs, H; barley as an internal standard, and C) PLBs lacking shoots.
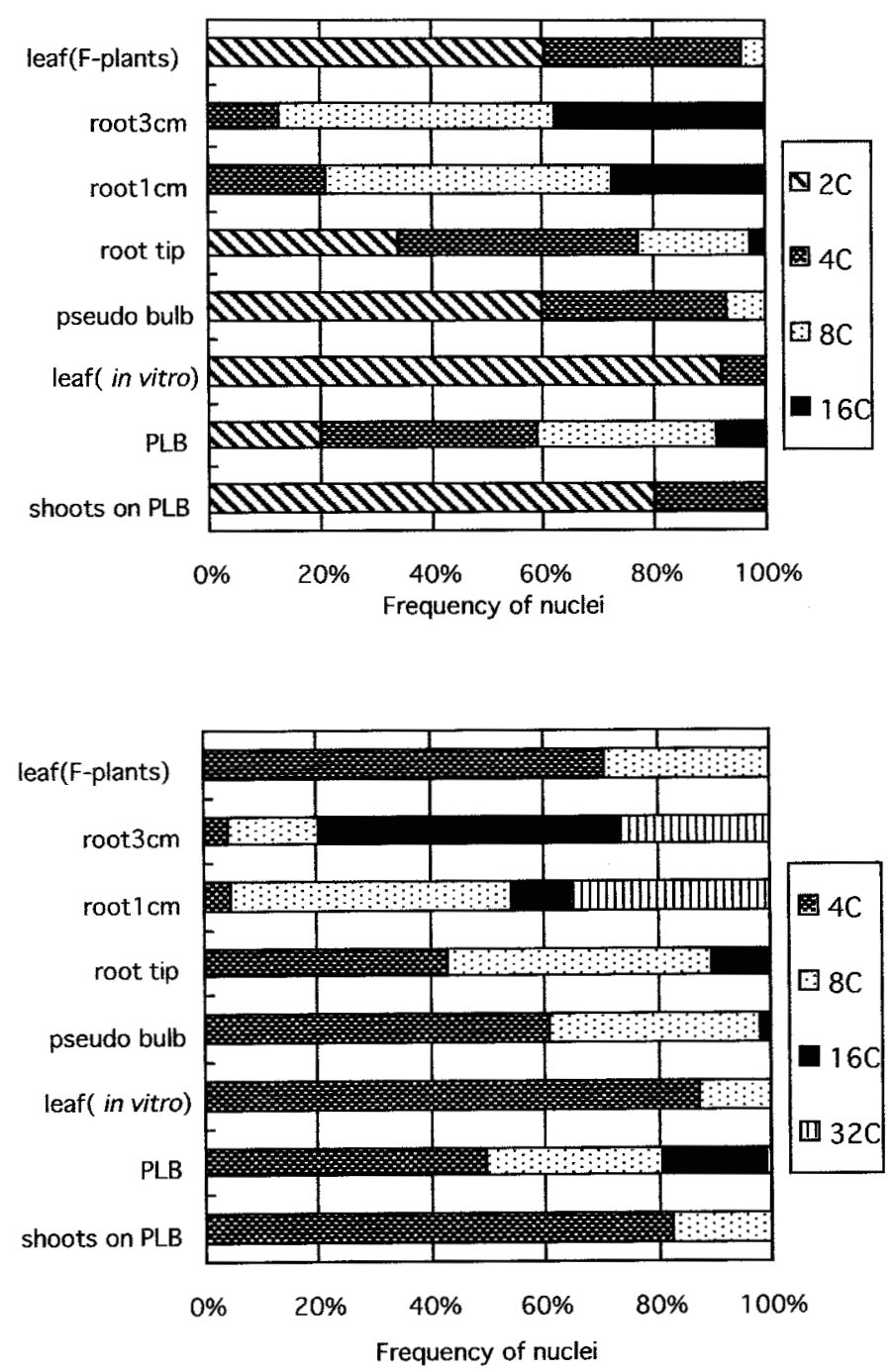

Fig. 2. Frequency of nuclei at different $\mathrm{C}$-values measured in various parts of Cymbidum 'Day Light' (upper) and 'Christmas Kiss' (lower). Leaf (F-plant); mature leaf from flowering plants, $\operatorname{root} 3 \mathrm{~cm}$, root $1 \mathrm{~cm}$; root tissue 1 or $3 \mathrm{~cm}$ apart from root tip, root tip; about $1 \mathrm{~mm}$ root growing tip, pseudo bulb; base of in vitro plant, leaf (in vitro); leaf from in vitro plant, PLB; PLB excluding shoots, shoots on PLB; 5 mm shoots on PLB. 4 to $32 \mathrm{C}$ in the tetraploid 'Christmas Kiss' is considered to correspond to 2 to $16 \mathrm{C}$ in the diploid 'Day Light'. 
But the obtained 2C value of 'Day Light' still does not support the idea that the occurrence of polysomaty relates to small genome size (De

Shoots regenerated from PLBs were 2C/ $4 \mathrm{C}$ as expected whereas PLBs showed more frequent polysomaty. This means that a meristematic center of PLBs remains euploid. In the micropropagation of epiphytic Cymbidium hybrids, PLBs are cut into small pieces and each piece produces some new protocorms on an appropriate medium. PLBs start to produce shoots if the cutting is postponed. New PLBs regenerate from epidermal cells, not from parenchyma cells inside of PLBs (Kim and Kako, 1984). In our study, epidermal tissue of PLBs showed only $2 \mathrm{C}$ and $4 \mathrm{C}$ peaks. Fujii et al. (1999) also reported that most cells in the outer tissue of Cymbidium PLBs had a DNA content of 2C while Nagl et al. (1972) observed that DNA amplification was restricted to the green assimilating parenchyma cells near the epidermis. Maintenance of euploidy in epidermal cells may be a reason why change of ploidy levels did not occur at a high frequency in micropropagated Cymbidium through PLB division. Begum et al. (1994) reported callus induction and PLB regeneration from the inner tissue of Cymbidium PLBs without deRocher et al., 1990).

scription of characteristics of the regenerants. Change of ploidy levels may occur at a higher frequency in this case. Increasing ploidy level in suspension culture of Doritaenopsis (Orchidaceae) was observed when 2,4-D or picloram was added to the culture medium (Mishiba et al., 2001). The strong selection of euploidy in regenerated plants has been reported in some callus and cell cultures having polyploidy and aneuploidy (Hahne and Hoffmann, 1986; Swedlund and Vasil, 1985), while considerable changes of chromosome numbers in regenerants was also observed in potato callus cultures (Ramulu and Dijkhuis, 1986).

Roots of Cymbidium were highly polysomatic as reported in Phalaenopsis (Mii et al., 1997) and Dendrobium (Jones and Kuehnle, 1998). No polysomaty was reported in Hosta roots (Zonneveld and Van Iran, 2000), but low and high levels of polysomaty were reported for potato (Ramulu and Dijkhuis, 1986) and tomato (Smulders et al., 1995) roots, respectively. Leaves taken from flowering Cymbidium plants were slightly polysomatic. This is considerably different from that in Phalaenopsis and Dendrobium which showed a high level of polysomaty in mature leaves. Floral organs of Cymbidium consisted of higher

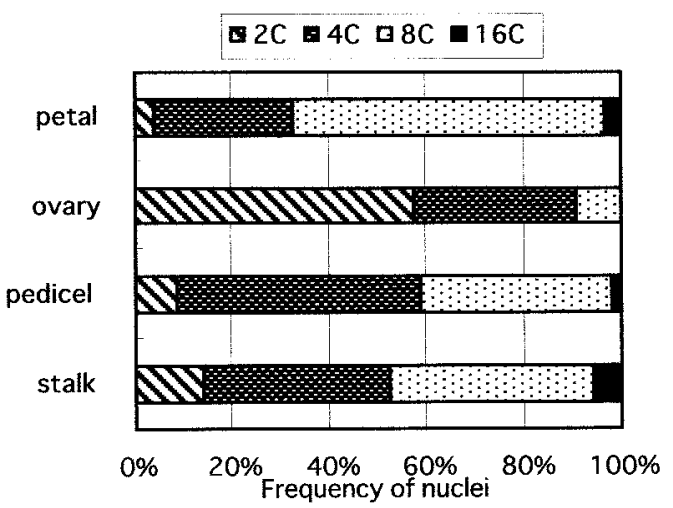

Fig. 3. Frequency of nuclei at different C-values measured in various floral parts of Cymbidium 'Day Light'.

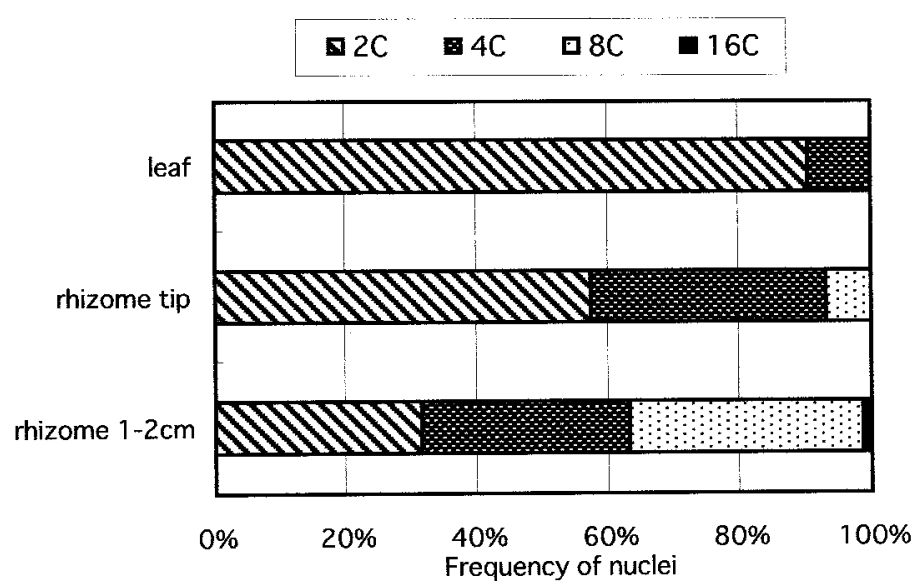

Fig. 4. Frequency of nuclei at different $C$-values measured in various parts of $C$. kanran Makino. Leaf; leaf from in vitro plants, rhizome tip; $\approx 0.5 \mathrm{~mm}$ growing tip, rhizome $1-2 \mathrm{~cm}$; rhizome tissue with $1-2 \mathrm{~cm}$ tip removed. ploidy cells except for the ovary. Development of polysomaty in floral organs, especially the perianth, has been reported in Portulaca (Mishiba and Mii, 2000).

The present results suggest that shoot regeneration arises from euploid cells and that endoreduplication occurs in cells without a potential for shoot regeneration.

In practice flow cytometry is a very useful tool to determine the ploidy level of plant materials. The present study showed that leaves from in vitro plants are suitable materials for flow cytometric analysis in Cymbidium as described in Dendrobium (Jones and Kuehnle, 1998).

\section{Literature Cited}

Aoyama, M. 1989. Karyomorphological studies in Cymbidium and its allied genera, Orchidacease. Bul. Hiroshima Bot. Garden 11:1-121.

Arditti, J. 1977. Cymbidium in orchid biology. Reviews and perspectives I. p. 233-239. Cornell Univ. Press, Ithaca.

Begum, A.A., M. Tamaki, M. Tahara, and S. Kako. 1994. Somatic embryogenesis in Cymbidium through in vitro culture of inner tissue of prptocorm-like bodies. J. Jpn. Soc. Hort. Sci. 63:419-427.

Bino, R.J., J.M. Van Tuyl, and J.N. DeVries. 1990. Flow cytometric determination of relative nuclear DNA contents in bicellulate and tricellulate pollen. Ann. Bot. 65:3-8.

Cavallini, A., R. Cremonini, G. Cionini, and P.G. Cionini 1988. Polysomaty and somatic reduction in Phaseolus coccineus L. Genome 30:671676.

De Rocher, E.J., K.R. Harkins, D.W. Galbraith, and H.J. Bohnert. 1990. Developmentally regulated systemic endopolyploidy in succulents with small genomes. Science 250:99-101.

Dolezel, J. 1997. Application of flow cytometry for the study of plant genomes. J. Appl. Genet. 38:285-302.

Dolezel, J., J. Greilhuber, S. Lucretti, A. Meister, M.A. Lysak, L. Nardi, and R. Obermayer. 1998 Plant genome size estimation by flow cytometry: Inter-laboratory comparison. Ann. Bot. 82 (Suppl. A):17-26.

Fujii, K., M. Kawano, and S. Kako. 1999. Effects of benzyladenine and $\alpha$-naphthalenacetic acid on cell division and nuclear DNA contents in outer tissue of Cymbidium explants cultured in vitro. J. Jpn. Soc. Hort. Sci. 68:41-48.

Galbraith, D.W., K.R. Harkins, and S. Knapp. 1991. Systemmic endopolyploidy in Arabidopsis thaliana. Plant Physiol. 96:985989.

Gilissen, L.J.W., M.J. Van staveren, J. CreemersMolenaar, and H.A. Verhoeven. 1993. Development of polysomaty in seedlings and plants of Cucumis sativus L. Plant Sci. 91:171-179.

Hasegawa, A. 1987. Studies on the propagation of oriental Cymbidium (in Japanese with English summary). Mem. Fac. Agr. Kagawa Univ. 50:1108.

Hahnne, B. and F. Hoffmann. 1986. Cytogenetics of protoplast cultures of Brachycome dichromosomatica and Crepis capillaris and regeneration of plants. Theor. Appl. Genet. 72:244-251.

Jones, W.E. and A.R. Kuehnle. 1998. Ploidy identification using flow cytometry in tissues of Dendrobium species and cultivars. Lindleana 13:11-18.

Kankanpää, J., L. Mannonen, and A.H. Schulman. 1996. The genome sizes of Hordeum species 
show considerable variation. Genome 39:730735 .

Kim, and S. Kako. 1984. Morphological and histochemical studies on protocorm-like bodies formation and explant development in the Cymbidium shoot apex culture in vitro. J. Kor. Soc. Hort. Sci. 25:156-163.

Melaragno, J.E., B. Mehrotra, and A.W. Coleman. 1993. Relationship between endoploidy and cell size in epidermal tissue of Arabidopsis. Plant Cell 5:1661-1668.

Mii, M., K. Mishiba, and K. Tokuhara. 1997. Polysomaty and ploidy determination in Phalaenopsis. Breed. Sci. 47(Suppl.2):373.

Mishiba, K., T. Ando, M. Mii, H. Watanabe, H. Kokubun, G. Hashimoto, and E. Marchesi. 2000. Nuclear DNA content as an index character discriminating taxa in the genus Petunia sensu Jussieu (Solanaceae). Ann. Bot. 85: 665-673.

Mishiba, K. and M. Mii. 2000. Polysomaty analysis in diploid and tetraploid Portulaca grandiflora. Plant Sci. 156:213-219.

Mishiba, K., T. Okamoto, and M. Mii. 2001. Increasing ploidy level in cell suspension cultures of Doritaenopsis by exogenous application of 24-dichlorophenoxyacetic acid. Physiol. Plant. 112:142-148.

Nagl, W.1972. Evidence of DNA amplification in the orchid Cymbidium in vitro. Cytbios 5:145154.

Nagl, W., J. Hendon, and W. Rünger. 1972. DNAS amplification in Cymbidium protocorms in vitro, as it relates to cytodifferentiation and hormone treatment. Cell Diff. 1:229-237.

Pijnacker, L.P., K.S. Ramulu, P. Dijkhuis, and M.A. Ferwerda. 1989. Flow cytometric and karyological analysisi of polysomaty and polyploidization during callus formation from leaf segments of various potato genotyes. Theor. Appl. Genet 77:102-110.
Ramulu, K.S. and P. Dijkhuis. 1986.Flow cytometric analysis of polysomaty and in vitro gengetic instability in potato. Plant Cell Rpt. 3:234-237.

Smulders, M.J.M., W. Rus-Kortekaas, and L.J. W.Gilissen.1994. Development of polysomaty during differentiation in diploid and teraploid tomato(Lycopersicon esculentum) plants. Plant Sci. 97:53-60.

Smulders, M.J.M., W. Rus-Kortekaas, and L.J. W.Gilissen. 1995. Natural variation in patterns of polysomaty among individual tomato plants and their regenerated progeny. Plant Sci. 106:129-139.

Swedlund, B. and I.K. Vasil. 1985. Cytogenetic characterization of embryogenic callus and regenerated plants of Pennisetum americanum (L.) Schum. Theor. Appl. Genet. 69:575-581.

Zonneveld, B.J.M. and F. Van Iren. 2000. Flow cytometric analysis of DNA content in Hosta reveals ploidy chimeras. Euphytica 111:105-110. 